\title{
Strategi pengembangan wisata alam Danau Tajwid di Kecamatan Langgam Kabupaten Pelalawan
}

\author{
Zulfikar $^{1}$, Sukendi ${ }^{2}$, Nofrizal $^{3}$ \\ ${ }^{1,2,3}$ Program Studi Ilmu Lingkungan Program Pascasarjana Universitas Riau \\ Diterima: 10 April 2021| Disetujui: 29 April 2021 | Diterbitkan: 30 April 2021
}

\begin{abstract}
This research aims to determine the impact of the development of Lake Tajwid natural tourism and the strategy of developing Lake Tajwid natural tourism. There are two data in this research, namely primary data and secondary data. data analysis using GAP analysis which is based on the SAPTA PESONA indicator. Sapta Pesona has 7 indicators, namely; safe, orderly, clean, beautiful, cool, friendly and memorable. based on the results of research on natural ecotourism development of Lake Tajwid impact on environmental, economic and social conditions. the environment will have an impact on environmental pollution if it is not wise in developing tourist areas. the economic aspect can grow the economy, the social aspect opens up employment opportunities. Then there is a gap between reality and charm. The strategies designed in this research to realize the natural tourism development of Lake Tajwid are; 1) instilling awareness of tourism, 2) structuring facilities and infrastructure, 3) increasing supporting facilities, 4) increasing information / innovation and promotion, and 5) preserving the environment.
\end{abstract}

Keywords: Natural Tourism Lake Tajwid; Strategy of Developing; Sapta Pesona

Kekayaan alam Kabupaten Pelalawan yang mempunyai potensi keparawisataan tidak kalah dengan daerah wisata lainnya. Marrioti (2006) potensi adalah segala sesuatu yang terdapat di daerah tujuan wisata, dan merupakan daya tarik agar orang-orang mau datang berkunjung ke tempat tersebut. Danau Tajwid merupakan salah satu potensi kawasan wisata yang bisa dikembangkan. Kawasan Wisata Alam Danau Tajwid adalah kawasan yang terletak di Kecamatan Langgam yang menyimpan segudang pesona alam yang asri. Danau yang masih bertaburkan ikan air tawar dari berbagai jenis. Danau Tajwid merupakan kawasan wisata alam yang masih terbilang baru namun disini kita dapat menikmati keindahan alam sekaligus memperluas pengetahuan tentang alam secara langsung dan juga dijadikan sebagai pengembangan ilmu pengetahuan mengenai berbagai macam jenis hewan dan tumbuhan serta ekosistemnya. Kawasan Wisata Alam Danau Tajwid di Kecamatan Langgam ini baru di hadirkan oleh Pemerintah Kabupaten Pelalawan sebagai kawasan wisata oleh kepemimpinan Bupati H. M. Harris dengan melihat potensi yang dimilikinya. Dengan baru dijadikan kawasan obyek wisata, wisata alam Danau Tajwid memiliki banyak kekurangan seperti; akses jalan meuju lokasi yang baru dibuat, area parkir kendaraan yang belum tertata dengan baik, sarana prasarana penunjang seperti rumah makan yang belum tersedia dengan baik dan lain sebagainya, sehingga wisatawan yang berkunjung ke Danau Tajwid ini hanya pada saat musim liburan saja. Hal ini yang menjadi pendorong penulis untuk melakukan penelitian di kawasan Wisata Alam Danau Tajwid di Kelurahan Langgam, Kecamatan Langgam, Kabupaten Pelalawan ini untuk mengelola lebih baik dari aktifitas yang telah berlangsung serta mengidentifikasi potensi yang ada untuk mengembangkan kawasan ini menjadi kawasan wisata alam seperti hutan lindung yang masih alami, taman yang terdapat di kawasan tersebut dan yang paling utama yaitu danau yang menjadi ciri khas di kawasan tersebut agar kawasan Wisata Alam Danau Tajwid ini dapat menjadi Obyek Wisata yang lebih diketahui dan diminati oleh wisatawan tidak hanya dari Kabupaten Pelalawan saja, akan tetapi dari daerah lain. Penelitain Strategi pengembangan Wisata Alam Danau Tajwid Kecamatan Langgam kabupaten Pelalawan bertujuan untu mengetahui; 1) Dampak pengembangan wisata Alam Danau Tajwid. 2) merancang strategi pengembangan wisata alam danau Tajwid.

\section{METODE PENELITIAN}

Waktu penelitian dilaksanakan pada bulan Juni 2020 hingga bulan Oktober 2020, di kawasan objek wisata alam Danau Tajwid, Kecamatan Langgam, Kabupaten Pelalawan. Metode penelitian meliputi metode wawancara observasi dan dokumentasi. Analisis data dalam penelitian ini menggunakan analisis kualitatif deskriftif untuk mengetahu dampak pegembangan wisata alam Danau Tajwid dan GAP analisis untuk mengetahui kesenjangan kenyataan dilokasi penelitain dengan indikator Sapta Pesona. 


\section{HASIL DAN PEMBAHASAN}

\section{Gambaran Lokasi Penelitian}

Kecamatan Langgam terletak dalam Kabupaten Pelalawan. Kecamatan langgam dapat ditempuh dengan waktu sekitar 30 menit dari Pangkalan Kerinci melalui jalan darat dan 45 menit menggunkan speedboat. Menuju Kecamatan Langgam selain ditempuh dari Pangkalan Kerinci, juga dapat menggunakan jalan darat dari Kuantan Singingi dan Pekanbaru. Sebagai kota tua peninggalan kerajaan Tambak yang terkenal dengan kolam tujuhnya, wisatawan juga dapat menikmati keindahan danaunya yang terkenal dengan Danau Tajwid. Dengan diaplikasikannya sistem inovasi daerah, Kecamatan Langgam terpilih sebagai lokasi bagi dibangunnya Teknopolitan yaitu sebuah konsep kawasan yang terintegrasi. Sekitar 38000 ha sudah dipersiapkan untuk lokasi pembangunan Teknopolitan ini (Pelalawantourism, 2020). Wisata Alam Danau Tajwid merupakan danau oxbow yang dikelilingi oleh hutan dengan status milik ulayat dan pemerintah daerah Kabupaten Pelalawan. Kawasan Danau Tajwid yang secara ekosistem memiliki ekosistem yang unik, saat ini memiliki keragaman hayati oleh flora dan fauna. Secara struktur vegetasi setiap stratum didominasi oleh jenis yang berbeda. Pada tingkat pohon didominasi dari jenis karet (Hevea brasiliensis) dan rengas (Gluta renghas), pada tingkat tiang didominasi oleh jenis kemedangan (Litsea sp.), pada tingkat pancang didominasi oleh jenis senduduk (Melastoma malabathricum) dan pada tingkat semai didominasi oleh jenis rumput kacangan (Asystasia gangetica). Komoditas hasil hutan bukan kayu yang saat ini telah dimanfaatkan adalah rotan dan lebah hutan. Danau Tajwid sampai saat ini masih dikuasai oleh adat dan dikelola secara adat serta pemanfaatannya masih bersifat konvensional.

\section{Dampak Pengembangan Wisata Alam Danau Tajwid}

Pengembangan suatu kawasan akan memberikan dampak pada aspek lingkungan, ekonomi dan sosial. Pengembangan Wisata Alam Danau Tajwid memberikan dampak langsung pada masyarakat sekitar. Berdasarkan hasil wawancara yang dilakukan diketahui dengan adanya Wisata Alam Danau Tajwid dapat meningkatkan perekonomian dan membuka lapangan pekerjaan. Masyarakat sekitar diperbolehkan berjualan dalam kawasan Wisata Alam Danau Tajwid, masyarakat direkrut untuk menjadi tenaga kerja seperti penunggu tiket masuk ke tempat permainan atau wahana yang disediakan di Wisata Akam Danau Tajwid. Dampak pengembangan dapat dilihat pada Tabel 1.

Tabel 1. Dampak pengembangan Wisata Alam Danau Tajwid

\begin{tabular}{cll}
\hline No & Aspek & Dampak pengembangan \\
\hline 1 & Lingkungan & Dapat mencemari lingkungan \\
2 & Ekonomi & Meningkatkan perekonomian \\
3 & Sosial & Membuka lapangan pekerjaan \\
\hline
\end{tabular}

Pencemaran lingkungan dapat menjadi dampak yang akan timbul dengan adanya pengembangan Wisata Alam Danau Tajwid. Kurangnya ketersediaan tempat sampah di beberapa lokasi wisata berpotensi dapat menyebabkan wisatawan membuang sampah sembarangan dan tentu saja hal ini dapat mencemari lingkungan. Pencemaran lingkungan merupakan dampak negatif dari adanya suatu pembangunan. Khalik (2014) keadaan lingkungan sekitar kawasan wisata harus terjaga dengan tidak membuang sampah sembarangan dan menjaga kebersihan pada fasilitas umum karena jika dipandang dari sudut pandang kesehatan lingkungan, membuang sampah sembarangan dapat menyebabkan penyakit dan dapat merusak ekosistem yang ada di sekitar serta dapat mempengaruhi kenyamanan wisatawan dalam melakukan kunjungan.

Selain dampak negatif terhadap lingkungan dari adanya pengembangan Wisata Alam Danau Tajwid ada juga dampak positif adanya Wisata Alam Danau Tajwid terhadap lingkungan, dampak positif masyarakat lebih ingin menjaga kawasan Danau Tajwid karena keberadaan objek wisata dapat membuka lapangan pekerjaan bagi masyarakat sekitar.

\section{Strategi Pengembangan Wisata Alam Danau Tajwid}

Sapta pesona merupakan indikator yang dijadikan untuk melihat kesenjangan yang ada di Wista Alam Danau Tajwid. Sapta pesona dirumuskan dalam Peraturan Menteri Kebudayaan dan Pariwisata Nomor PM. 04/UM.001/MKP/2008 tentang Sadar Wisata. Dari indikator tersebut dirumuskan strategi untuk pengembangan Wisata Alam Danau Tajwid. Indikator Sapta Pesona dapat dilihat pada Tabel 2. 
Tabe1 2. Indikator Sapta Pesona

\begin{tabular}{|c|c|}
\hline No & Sapta Pesona \\
\hline \multirow[t]{8}{*}{1} & Aman : \\
\hline & 1. Tidak menganggu kenyamanan wisatawan \\
\hline & 2. Menolong dan melindungi wisatawan \\
\hline & 3. Menunjukkan sifat bersahabat terhadap wisatawan \\
\hline & 4. Memelihara keamanan lingkungan \\
\hline & 5. Membantu memberi informasi kepada wisatawan \\
\hline & 6. Menjaga lingkungan yang bebas dari bahaya penyakit menular \\
\hline & 7. Meminimalkan resiko kecelakaan dalam penggunaan fasilitas publik \\
\hline \multirow[t]{5}{*}{2} & Tertib : \\
\hline & 1. Mewujudkan budaya antri \\
\hline & 2. Memelihara lingkungan dengan mentaati peraturan yang berlaku \\
\hline & 3. Disiplin waktu/tepat waktu \\
\hline & 4. Serba jelas, teratur, rapi dan lancar. \\
\hline \multirow[t]{7}{*}{3} & Bersih : \\
\hline & 1. Tidak membuang sampah sembarangan \\
\hline & 2. Menjaga kebersihan lingkungan objek wisata \\
\hline & 3. Menjaga lingkungan yang bebas dari polusi udara \\
\hline & 4. Menyiapkan sajian makanan dan minuman yang higienis \\
\hline & 5. Menyiapkan perlengkapan penyajian makanan dan minuman yang bersih \\
\hline & 6. Pakaian dan penampilan petugas bersih dan rapi \\
\hline \multirow[t]{4}{*}{4} & Sejuk : \\
\hline & 1. Melaksanakan penghijauan dengan menanam pohon \\
\hline & 2. Memelihara penghijauan di lingkungan objek wisata \\
\hline & 3. Menjaga kondisi sejuk dalam berbagai area di daerah tujuan wisata \\
\hline \multirow{4}{*}{5} & Indah : \\
\hline & 1. Menjaga objek wisata dalam tatanan yang estetik, alami dan harmoni \\
\hline & 2. Menata lingkungan secara teratur \\
\hline & 3. Menjaga keindahan vegetasi, tanaman hias dan peneduh. \\
\hline \multirow[t]{5}{*}{6} & Ramah \\
\hline & 1. Bersikap sebagai tuan rumah yang baik serta selalu membantu wisatawan \\
\hline & 2. Memberi informasi tentang adat istiadat secara sopan \\
\hline & 4. Menunjukkan sikap menghargai dan toleransi terhadap wisatawan \\
\hline & 3. Memberikan senyum yang tulus. \\
\hline \multirow[t]{4}{*}{7} & Kenangan \\
\hline & 1. Menggali dan mengangkat keunikan budaya lokal \\
\hline & 2. Menyajikan makanan dan minuman khas lokal yang bersih dan sehat \\
\hline & 3. Menyediakan cinderamata yang menarik, unik/khas serta mudah dibawa \\
\hline
\end{tabular}

Berdasarkan hasil penelitain bahwa sapta pesona sudah diterapkan di Wisata Alam Danau Tajwid. Namun, dalam pengembangan Wisata Alam Danau Tajwid masih saja terjadi kesenjangan antara sapta pesona dan kenyataan yang ada. Kesenjangan sapta pesona dengan kenyataan yang ada dapat dilihat pada Tabel 3.

Tabel 3. Sapta Pesona dan Kenyataan

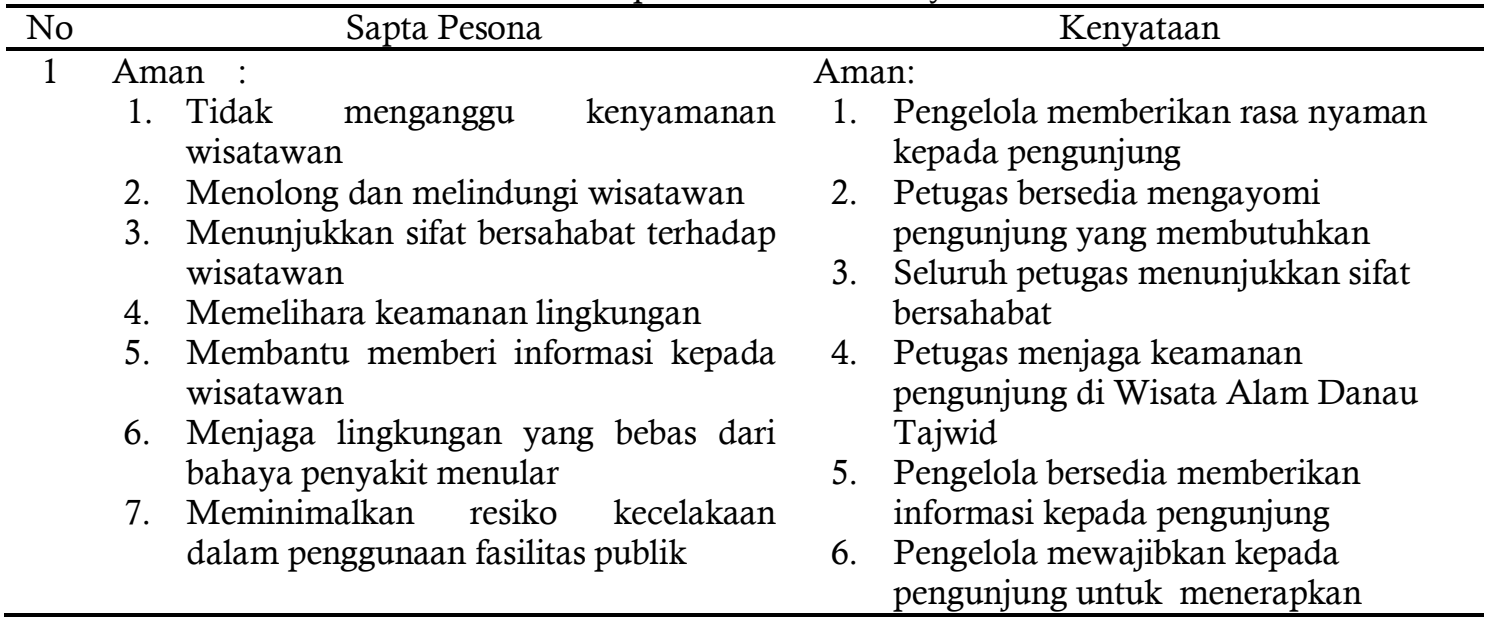


protokol kesehatan pencegahan penularan Covid 19

7. Pengelola masih kurang dalam penyediaan sarana dan prasarana yang belum lengkap yang mengakibatkan timbulnya kecelakan bagi pengunjung

2 Tertib :

1. Mewujudkan budaya antri

2. Memelihara lingkungan mentaati peraturan yang berlaku

3. Disiplin waktu/tepat waktu

4. Serba jelas, teratur, rapi dan lancar.

3 Bersih :

1. Tidak membuang sampah sembarangan

2. Menjaga kebersihan lingkungan objek wisata

3. Menjaga lingkungan yang bebas dari polusi udara

4. Menyiapkan sajian makanan dan minuman yang bersih dan higienis

5. Pakaian dan penampilan petugas bersih dan rapi

4 Sejuk :

1. Melaksanakan penghijauan dengan menanam pohon

2. Memelihara penghijauan di lingkungan objek wisata

3. Menjaga kondisi sejuk dalam berbagai area di daerah tujuan wisata

5 Indah :

1. Menjaga objek wisata dalam tatanan yang estetik, alami dan harmoni

2. Menata lingkungan secara teratur

3. Menjaga keindahan vegetasi, tanaman hias dan peneduh

6 Ramah :

1. Bersikap sebagai tuan rumah yang baik serta selalu membantu wisatawan

2. Memberi informasi tentang adat istiadat secara sopan

3. Menunjukkan sikap menghargai dan toleransi terhadap wisatawan

4. Memberikan senyum yang tulus
Tertib:

1. Pengelola memberlakukan sistem antri

2. Belum memberlakukan SOP pada berbagai fasilitas dan wahana

3. Pengelola menerapkan disiplin waktu

4. Pengelola belum maksimal dalam menerapkan ketertiban dalam Bersih: kawasan Wisata Alam Danau Tajwid

1. Pengelola belum menyediakan tempat sampah yang memadai

2. Pengelola sudah menerapkan untuk menjaga kebersihan

3. Lingkungan terbebas dari polusi udara

4. Belum tersedianya sarana dan prasarana makanan dan minuman

5. Petugas belum menggunakan pakaian seragam

Sejuk:

1. Pengelola belum melakukan penghijaun

2. Pengelola sudah memelihara vegetasi dan tumbuhan disekitar kawasan Wisata Alam Danau Tajwid

3. Kondisi tanaman yang terjaga memberikan suasana sejuk bagi pengunjung

Indah:

1. Pengelola belum menata secara maksimal objek Wisata Alam Danau Tajwid

2. Pengelola belum menata lingkungan secara teratur

3. Pengelola belum maksimal dalam menjaga keindahan vegetasi, tanaman hias dan peneduh

Ramah:

1. Pengelola dan masyarakat ramah terhadap pengunjung

2. Pengelola dan masyarakat bersedia memberikan informasi kepada pengunjung mengenai adat istiadat

3. Pengelola dan masyarakat menunjukkan sikap menghargai dan toleransi terhadap pengunjung

4. Pengelola dan msyarakat senang memberikan senyuman yang tulus kepada pengujung 
ZONA

Jurnal Lingkungan

ISSN : 2502-6496 (Print) | 2502-6496 (Online)

Volume 5, No 1, April 2021, p. 21-28

http://zona.pelantarpress.co.id

\begin{tabular}{lll}
\hline 7 & Kenangan : & Kenangan: \\
1. Menggali dan mengangkat keunikan & 1. & $\begin{array}{l}\text { Belum adanya kegiatan yang } \\
\text { menunjukkan keunikan budaya lokal } \\
\text { budaya lokal }\end{array}$ \\
& 2. $\begin{array}{l}\text { Belum maksimalnya pengelola dan } \\
\text { 2. Menyajikan makanan dan minuman }\end{array}$ \\
$\begin{array}{l}\text { khas lokal yang bersih dan sehat } \\
\text { 3. Menyediakan cinderamata yang menyediakan } \\
\text { menarik, unik/khas serta mudah } \\
\text { dibawa }\end{array}$ & 3. $\begin{array}{l}\text { makanan dan minuman khas lokal } \\
\text { Belum tersedianya cinderamata }\end{array}$ \\
\hline
\end{tabular}

Tabel 3 menunujukkan indikator sapta pesona dengan kenyataan di Wisata Alam Danau Tajwid. Indikator aman sudah diterapkan dengan melakukan penutupan sementara kawasan Wisata Alam Danau Tajwid dalam upaya pencegahan penularan Covid 19. Namun sebelum kebijakan penutupan sementara diberlakukan pengunjung memasuki kawasan dengan mematuhi protokol kesehatan. Indikator aman dapat memberikan manfaat, yaitu ; 1) Tidak ada rasa takut untuk bepergian. 2) Keinginan wisatawan untuk berkunjung lebih besar. 3) Citra positif pariwisata tetap terjaga. 4) Memberikan peluang pembangunan dan penyempurnaan fasilitas dan sistem pelayanan jasa informasi yang bermanfaat baik di tempat-tempat obyek wisata maupun di tempat-tempat lain.

Indikator tertib seharusnya sudah diterapkan di Wisata Alam Danau Tajwid. Namun untuk mengetahui bagiamana ketertiban di kawasan Wisata Alam Danau Tajwid tidak sepenuhnya dapat diketahui. Hal ini dikarenakan pada saat melakukan penelitian tidak banyak pengunjung karena adanya pandemi Covid 19. Indikator tertib dapat memberikan manfaat; 1) Terciptanya ketenangan. 2) Terciptanya kondisi teratur. 3) Terbentuknya wibawa sebagai masyarakat yang berbudaya.

Indikator bersih merupakan indikator sapta pesona yang ketiga. Kebersihan kawasan Wisata Alam Danau Tajwid pada saat melakukan penelitian terjaga dengan bersih. Tidak ditemukan sampah yang berserakan atau dibuang disembarang. Keadaan seperti ini tentu saja akan berbeda jika volume pengunjung seperti bulan-bulan sebelumnya. Pandemi covid 19 membuat jumlah kunjungan menurun dan adanya kebijakan penutupan sementara Wisata Alam Danau tajwid membuat sedikit jumlah kunjung dan meminimalisir keberadaan sampah. Minimnya tempat sampah tentu menjadi persolaan jika jumlah pengu jung meningkat hal ini dikhawatirkan adanya tindakan membuang sampah sembaranagn. Manfaat menerapkan indikator bersih yaitu; 1) Pola hidup sehat. 2) Suasana hidup yang lebih menyenangkan. 3) Semangat hidup yang lebih bergairah.

Indikator sapta pesona selanjutnya yaitu sejuk. Kondisi ini merupakan suatu kondisi di destinasi pariwisata/daerah tujuan wisata yang mencerminkan keadaan yang sejuk dan teduh yang akan memberikan perasaan nyaman bagi wisatawan dalam melakukan kunjungannya ke daerah tersebut. Wisata Alam Danau Tajwid keindahan alam dan alamnya yang masih alami memberikan susana sejuk saat berada di dalam kawasan Wisat Alam Danau Tajwid. Inidkator sejuk sudah dipastikan dapat ditemukan pada Wisata Alam Danau Tajwid. Kondisi sejuk ada kawasan objek wisata dapat memberikan manfaat; 1)Tubuh dan pikiran kita menjadi segar dan fit setiap saat. 2) Stamina kita dalam beraktivitas bertahan lebih lama.

Indikator sapta pesona yang kelima yaitu indah. Objek wsiata dikatakan indah jika kondisi di daerah tujuan wisata yang mencerminkan keadaan yang indah dan menarik dan memberikan kesan yang mendalam bagi wisatawan sehingga mewujudkan potensi kunjungan ulang serta mendorong promosi ke pasar wisatawan yang lebih luas. Manfaat indikator indah yaitu; 1) Timbulnya kesadaran akan kebesaran Tuhan. 2) Terciptanya perasaan senang. 3) Mencegah munculnya perasaan stress. 4) Mempertajam kepekaan estetis. Wisata Alam danau Tajwid karena keindahan dan keunikan kawasan merupakan alasan utama pengunjung datang berwisata ke Wisata Alam Danau Tajwid.

Indikator keenam dari sapta pesona yaitu ramah. Ramah merupakan Suatu kondisi lingkungan yang bersumber dari sikap masyarakat di destinasi pariwisata yang mencerminkan suasana yang akrab dan terbuka. Berdasarkan observasi yang dilakukan selama penelitain masyarakat sekitar bersikap ramah terhadap pengunjung/wisatawan. Masyarakat tidak enggan memberikan informasi dan mudah untuk diajak berinteraksi. Manfaat ramah dalam pengembangan wisata yaitu; 1) Terjadinya keakraban; dengan tegur-sapa suasana hangat akan senantiasa tercipta dalam perasaan setiap individu meskipun tidak saling mengenal satu dengan lainnya. 2) Terciptanya rasa damai keakraban yang tercipta pada akhirnya tentu membuat hati kita menjadi damai, tanpa rasa was-was meski berada di lingkungan dan orang-orang yang asing bagi kita. 3) Mencegah terjadinya konflik; melalui tegur sapa bisa tercipta tali persaudaraan dan kekeluargaan yang akan mampu mencegah terjadinya konflik. 


\section{ZONA}

Selanjutnya indikator sapta pesona yang ketujuh yaitu kenangan. Suatu bentuk pengalaman yang berkesan di destinasi pariwisata yang akan memberikan rasa senang dan kenangan yang indah bagi wisatawan. Manfaat kenangan yaitu ; 1) Terbentuknya penghormatan dan penghargaan dari orang lain. 2) Terbentuknya citra yang baik bagi pribadi, masyarakat, dan negara kita. 3) Terciptanya kepuasan bagi diri kita dan terlebih bagi wisatawan. 4) Meningkatkan rasa saling percaya di antara sesama.

Meminimalisir kesenjangan antara sapta pesona dengan keadaan Wisata Alam Danau Tawid yang sebenarnya diperlukan adanya strategi yang tepat agar upaya dalam pengembangan Wisata Alam Danau Tawid dapat diwujudkan dan berjalan dengan baik. Startegi yang pertama sekali dilakukan adalah dengan menerapkan sadar wisata kepada masyarakat, pengunjung dan pengelola. Sadar wisata merupakan suatu kondisi yang menggambarkan partisipasi dan dukungan segenap komponen masyarakat dalam mendorong terwujudnya iklim yang kondusif bagi tumbuh dan berkembangnya kepariwisataan di suatu destinasi atau wilayah.

Pengembangan destinasi wisata harus dengan prinsip-prinsip ekowisata agar terjaga kelestarian lingkungan. Wisata Alam Danau Tajwid dibentuk pada tempat yang menjunjung tinggi adat istiadat masyarakat, dibangun pada tempat yang hasil danaunya dimanfaatkan secara langsung oleh masyarakat. Pemanfaatan secara langsung tersebut seperti pemanfaatan mencari ikan di Danau Tajwid. Ekowisata merupakan perjalanan alam yang mencerahkan yang berkontribusi pada konservasi ekosistem sambil menghormati integritas masyarakat setempat. Dua pandangan tentang ekowisata yaitu berkontribusi pada konservasi ekosistem dan menghormati integritas masyarakat setempatdapat digunakan untuk melestarikan sumber daya yang menjadi dasar produk ekowisata. Ekowisata memerlukan integrasi yang efektif dari kedua pandangan, sehingga baik industri dan sumber daya dapat dipertahankan dalam jangka panjang (Wight, 1993).

Ekowisata melibatkan perjalanan ke tujuan dimana flora, fauna, dan warisan budaya sebagai daya tarik utama. Salah satu tujuan dari ekowisata adalah untuk menawarkan wawasan wisatawan tentang dampak manusia terhadap lingkungan, dan untuk menumbuhkan apresiasi yang lebih besar terhadap habitat alami. Ekowisata yang bertanggung jawab meminimalkan aspek negatif dari pariwisata konvensional lingkungan dan meningkatkan integritas budaya masyarakat setempat. Karena itu, selain mengevaluasi faktor lingkungan dan budaya, bagian integral dari ekowisata adalah promosi daur ulang, energi efisiensi, konservasi air, dan penciptaan peluang ekonomi bagi masyarakat lokal (Kara et al. 2011).

Prinsip-prinsip ekowisata menurut Damanik et al (2006); 1). Mengurangi dampak negatif berupa kerusakan atau pencemaran lingkungan dan budaya lokal akibat kegiatan wisata. 2). Membangun kesadaran dan penghargaan atas lingkungan dan budaya dengan tujuan wisata, baik pada diri wisatawan, masyarakat lokal, maupun pelaku wisata lainnya. 3). Menawarkan pengalaman-pengalaman positif bagi wisatawan maupun masyarakat lokal, melalui kontak budaya yang lebih intensif dan kerjasama dalam pemeliharaan atau konservasi daerah tujuan objek wisata. 4). Memberikan keuntungan finansial secara langsung bagi keperluan konservasi melalui kontribusi atau pengeluaran ekstra wisatawan. 5). Memberikan keuntungan finansial dan pemberdayaan bagi masyarakat lokal, dengan menciptakan produk wisata yang mengedepankan nilai-nilai lokal. 6). Memberikan kepekaan terhadap situasi sosial, lingkungan dan politik di daerah tujuan wisata. 7). Menghormati hak asasi manusia dan perjanjian kerja, dalam arti memberikan kebebasan kepada wisatawan dan masyarakat lokal untuk menikmati atraksi wisata sebagai wujud hak asasi, serta tunduk kepada aturan main yang adil dan disepakati bersama dalam pelaksanaan transaksitransaksi wisata.

Selanjutnya strategi yang bisa dilakukan dalam upaya pengembangan Wisata Alam Danau Tajwid dengan lebih menata kembali sarana dan prasarana di Wisata Alam Danau Tawid. Menyediakan papan bacaan petunjuk yang dapat memudakan pengunjung, menyediakan lahan parkir yang teratur, menyediakan tempat penjualan cinderamata seperti makanan khas daerah ataupun kreasi berupa kerajinan tangan masyarakat lokal. Pemberdayaan masyarakat sekitar merupakan wujud dari keberasilan sadar wisata.

Meningkatkan fasilitas pendukung juga merupakan langkah strategi yang tepat dalam upaya pengembangan Wisata Alam Danau Tajwid. Srategi pengembangan yang dapat dilakukan seperti menyediakan beberapa paket wisata yang dibutuhkan oleh wisatawan. Pengembangan fasilitas pendukung dilakukan dengan adanya kerjasama yang baik antara pihak pemerintah dan pihak pengelola Wisata Alam Danau Tajwid. Meningkatkan fasilitas pendukung juga bisa dilakukan dengan memaksimalkan toko souvenir melalui masyarakat sekitar untuk menigkatkan pendapatan. Toko Souvenir di obyek Wisata Alam Danau Tajwid belum ada sehingga perlu mengembangkan toko souvenir melalui hasil kerajinan atau keterampilan dari warga lokal untuk meningkatkan pendapatan masyarakat, juga untuk memberikan kesan 
tersendiri terhadap wisatawan yang datang berkunjung agar hal tersebut menjadi bagian dari daya tarik wisata bagi wisatawan selanjutnya.

Meningkatkan informasi tentang jangkauan dan jarak tempuh melalui teknologi yang ada dan melalui pembicaraan positif dari wisatawan ke orang lain. Strategi ini terkait dengan kemudahan pengetahuan wisata untuk mengetahui jarak tempuh menuju Wisata Alam Danau Tajwid. Hal ini tentunya memberikan kemudahan untuk lebih banyak wisatawan yang berkunjung di obyek Wisata Alam danau Tajwid. Pemanfaatan media sosial juga merupakan strategi yang tepat dalam upaya pengembangan kawasan wisata. Media sosial berguna untuk mempromosikan Wisata Alam Danau Tajwid agar lebih dikenal oleh masyarakat luas. Di era globalisasi masyarakat lebih senang mencari informasi melalui jejaring sosial ataupun internet.

Strategi terakhir yang dapat dilakukan yaitu berusaha memelihara dan melestarikan keragaman alam. Strategi ini terkait dengan fenomena alam yang bisa terjadi di obyek wisata sehingga terus bertahan dan berusaha memelihara dan melestarikan lingkungan sekitar dengan melakukan penghijauan atau reboisasi yang berkelanjutan agar tidak terjadi erosi dan sedimentasi yang mengakibatkan terjadinya pendangkalan danau.

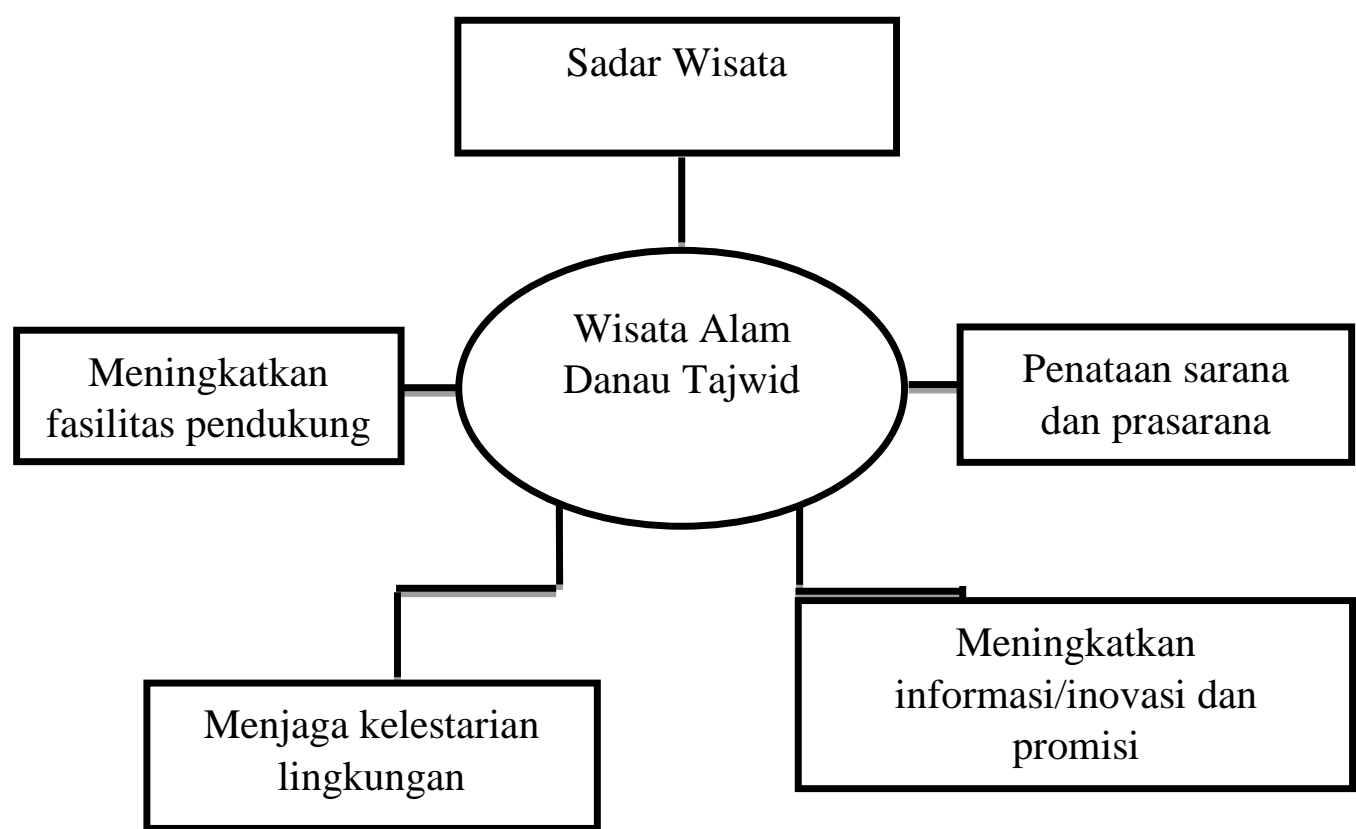

Gambar1. Rancangan strategi pengembangan Wisata Alam Danau Tajwid

\section{KESIMPULAN}

Dampak pengembanganWisata Alam Danau Tajwid terdapat pada tiga aspek (lingkungan, ekonomi, dan sosial). Dampak negatif terhadap lingkungan dapat mencemari lingkungan dan dampak positif terhadap lingkungan keberadaan Wisata Alam Danau Tajwid menjadi penting untuk dijaga dan dipelihara. Aspek ekonomi dapat menumbuhkan perekonomian. Aspek sosial membuka lapangan pekerjaan.Strategi pengembangan Wisata Alam Danau Tajwid dapat dilakukan dengan; menanamkan pola sadar wisata, penataan sarana dan prasarana, meningkatkan fasilitas pendukung, meningkatkan informasi/inovasi dan promosi, menjaga kelestarian lingkungan.

\section{DAFTAR PUSTAKA}

Damanik, J. Weber H,F. (2006). Perencanaan Ekowisata dari Teori ke Aplikasi. Yogyakarta.

Kara, B. Bulent, D. Cigdem, K. Zohre, P. (2011). Evaluation of Koçarlı Adnan in Terms ff The Ecotourism. Procedia Social and Menderes University. Turkey.

Khalik, W. (2014). Kajian Kenyamanan Dan Keamanan Wisatawan Di Kawasan Lombok. JUMPA (Jurnal Magister Pariwisata) Vol 01
Behavioral Sciences

Menderes Urban Forest

19: 145-149. Adnan

Pariwisata

Kuta 
Marrioti, NG. (2006). Principles of Food Sanitation 5ed. New York.

Wight, P. 1993. Ecotourism: Ethics or Eco-sell? Journal of Travel Research. Boulder 3: 3.

Wisata Alam Danau Tajwid. pelalawantourism.com./kecamatan/index/page(diakses pada tanggal 05 Oktober 2020).

Peraturan Menteri Kebudayaan dan Pariwisata. 2008. Tentang Sadar Wisata.Sekretariat Negara. Jakarta. 